\title{
VERTICAL TECTONIC MOTION IN ANDAMAN ISLANDS DETECTED BY MULTI-TEMPORAL SATELLITE RADAR IMAGES
}

\author{
Parcharidis Is. ${ }^{1}$, Foumelis M. ${ }^{2}$, and Lekkas E. ${ }^{3}$ \\ ${ }^{1}$ Harokopio University of Athens, Department of Geographyy, parchar@hua.gr \\ ${ }^{2}$ National and Kapodistrian University of Athens, Faculty of Geology and Geoenvironment, \\ Department of Geophysics - Geothermics, mfoum@geol.uoa.gr \\ ${ }^{3}$ National and Kapodistrian University of Athens, Faculty of Geology and Geoenvironment, \\ Department of Dynamic Tectonics Applied Geology, elekkas@geol.uoa.gr
}

\begin{abstract}
On 26 December 2004 one of the largest earthquakes ever recorded by modern seismology $(M w>9.0)$ occurred in Sumatra-Andaman region. About $1300 \mathrm{~km}$ of seafloor were ruptured extending from northern Sumatra to Andaman Island complex. As instrumental data are sparse and in most of the cases field observations difficult to undertake, the role of remote sensing may be beneficial in providing information about the pattern of deformation in space and time. In the present study ENVISAT ASAR data are acquired and processed to generate a single multitemporal SAR image in order to detect vertical motion along Andaman Island. According to our analysis it seems that the northern parts of the island are generally uplifted. Though its north-western coasts show significant marks of uplift, such indications become less evident along the western coasts of Middle Andaman. At some locations at the south-eastern margins of the island marks of downlift are recognized. Characteristic banding observed in the multi-temporal image could be attributed either to post-seismic relaxation, either to tidal phenomena. Although qualitative in nature, as just the sign of elevation change can be detected, results of such analysis could be used as constrains in deformation modelling research.
\end{abstract}

Key words: Vertical deformation, SAR, Multi-temporal image, Andaman Islands.

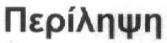

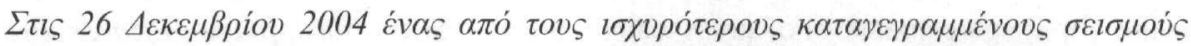

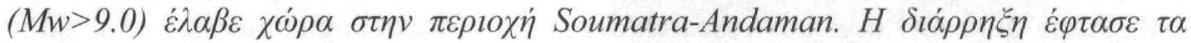

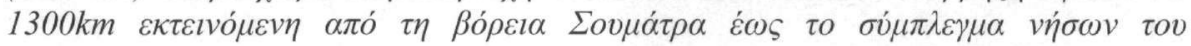

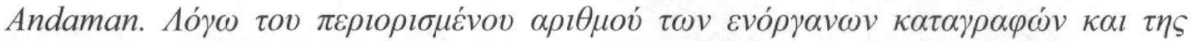

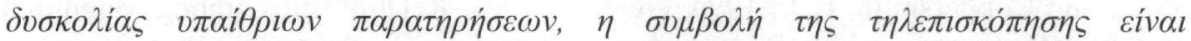

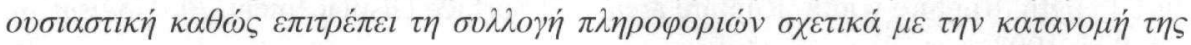

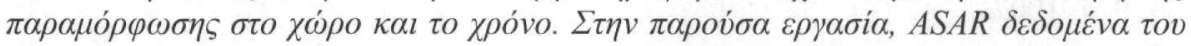

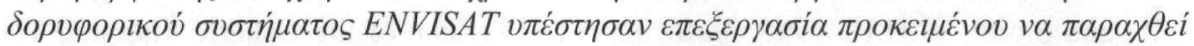

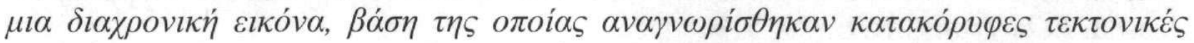

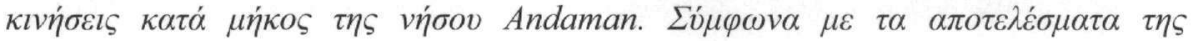




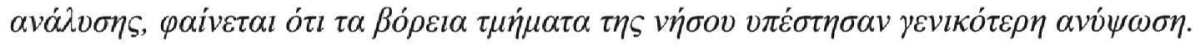

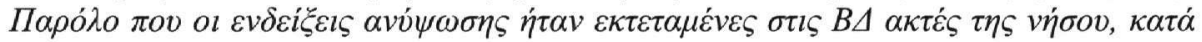

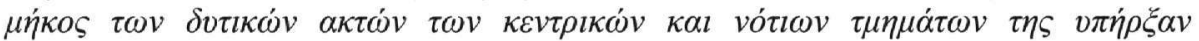

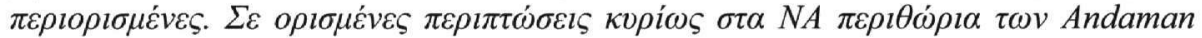

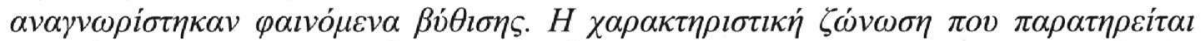

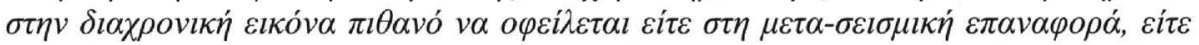
$\sigma \varepsilon \pi \alpha \lambda \imath \rho \rho о \ddot{\kappa} \alpha \dot{~ \varphi \alpha \imath v o ́ \mu \varepsilon v \alpha . ~ П \alpha \rho \alpha ́ ~ \tau o v ~ \pi о л о \tau \imath к o ́ ~ \chi \alpha \rho \alpha \kappa \tau \eta ́ \rho \alpha ~ \tau \omega v ~ \pi \alpha \rho \alpha \tau р \eta ́ \sigma \varepsilon \omega v, ~ \varepsilon \varphi o ́ \sigma o v ~}$

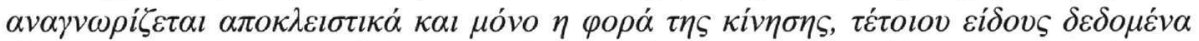

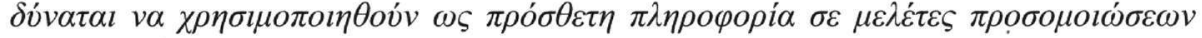
$\tau \eta \varsigma \pi \alpha \rho \alpha \mu o ́ \rho \varphi \omega \sigma \eta \varsigma$.

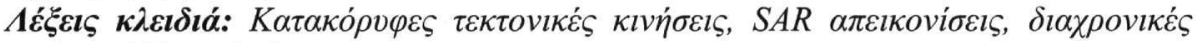

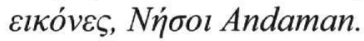

\section{Introduction}

On 26 December 2004 one of the largest earthquakes ever recorded by modern seismology $(\mathrm{Mw}>9.0)$ occurred in the Sumatra-Andaman subduction zone where the Indo-Australian plate underthrusts the Burmese plate (Lay et al. 2005, Stein and Okal 2005). Although south of the 2004 event, the Sumatran section of the Sunda megathrust have generated great earthquakes in 1797, 1833 (M 9) and 1861 (M 8.5) (Newcomb and McCann 1987), no historical record of great earthquakes $(\mathrm{M} \geq 8)$ have been reported from the Andaman-Nicobar and northern Sumatra region, though major events have occurred in 1847 (M7.5), 1868, 1881 (M7.9) and 1941 (M7.7) (Subarya et al. 2006). Paleaogeodetic studies based on coral records suggest that earthquakes of such magnitude occur in this region every 200-300 years (Natawidjaja et al. 2004, Sieh 2005).

The mainshock epicenter (00:58:53 GMT) was located $40 \mathrm{~km} \mathrm{NW}$ of Simeulue Island at $3.36^{\circ} \mathrm{N}$, $96.0^{\circ} \mathrm{E}$ at a depth of $30 \mathrm{~km}$ (Earnest et al. 2005) (Fig. 1). Harvard moment tensor solution.(CMT) suggests thrusting on a shallowly dipping plane $\left(8^{\circ}\right)$, striking $328^{\circ}$. The extension of the rupture zone, which reached about $1300 \mathrm{~km}$ roughly coincides with the aftershock distribution (Bilham et al. 2005, Guilbert et al. 2005).

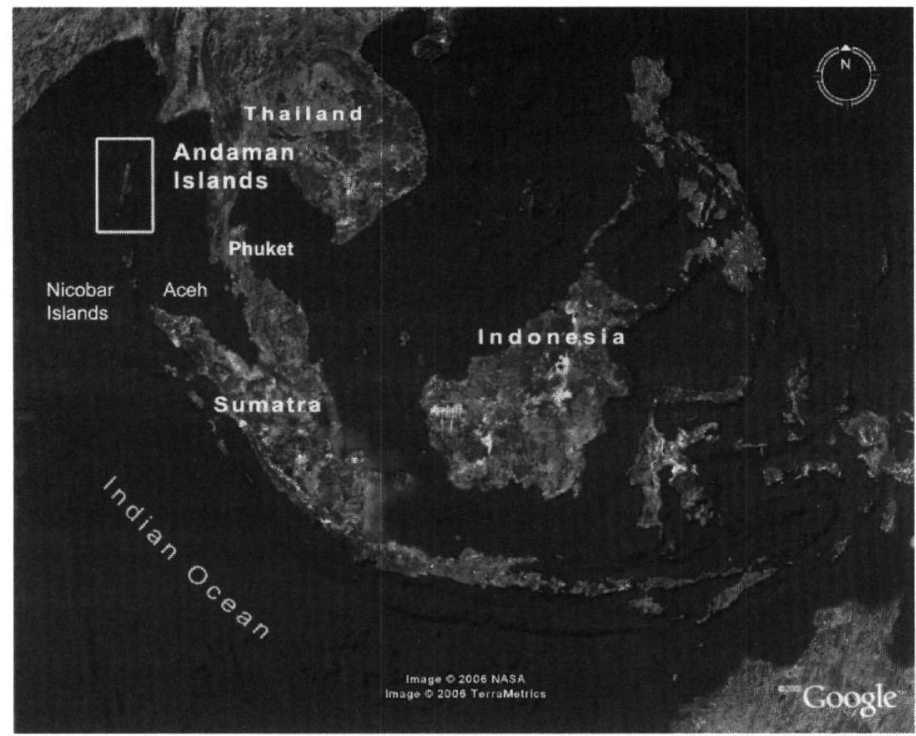

Figure 1 - Location map of Andaman Island complex

The rupture took about $500 \mathrm{~s}$ to propagate from the hypocentre in northern Sumatra to the northern Andaman Islands with a non-uniform speed (Ammon et al. 2005, Ni et al. 2005, Stein and Okal 
2005) According to some researchers much of the slippage occurred in the Andaman- Nicobar region the subsequent $1-\mathrm{h}$ period after the mainshock and continued as long as three hours afterward (Banerjee et al. 2005, Bilham et al. 2005). Vigny et al. 2005 also argued against slow slip based on regional GPS measurements.

During the two months followed the mainshock, nearly 1000 earthquakes occurred, while about 600 events occurred during a short duration from 27 to 30 January 2005 and nearly 100 of them were of magnitude $\geq 5$ (NEIC). Focal mechanisms of the aftershocks suggest arc-normal compression along the subduction front and extension in the back arc region (Anu and Rajendran 2006).

Data from a variety of sources, principally seismic data and Global Positioning System (GPS) measurements have been used to describe ground deformation related to the earthquake (Banerjee et al. 2005, Jade et al. 2005, Vigny et al. 2005). In-situ observations on coral microatoll morphology have also identified regions of shoreline changes (Sieh et al. 1999, Zachariasen et al. 2000). However such techniques provide insight of the local deformation, but lacks in describing the whole pattern of deformation regime alone. Remote sensing could provide significant information especially in the case of sparse instrumental data and where field observations are difficult.

In the present study Synthetic Aperture Radar (SAR) images were processed in order to detect areas of seismic uplift and downlift. As a supplementary source of information, satellite imagery from selected bands of Landsat 7 ETM+ was used. The time interval considered (from June 2004 to March 2005) is determined by the acquisition time of SAR images, which does not incorporate the largest aftershock followed the main event on 28 March 2005 (Mw 8.7).

Combinations of pairs of SAR images instead of the use of three successive acquisitions as colour composite for vertical deformation detection was applied in previous studies (Tobita et al. 2006). The advantage of the present technique is that spatial as well as temporal behaviour of deformation can be explored using a single multi-temporal image. Although both uplift and downlift can be robustly detected in several locations (sign of elevation change), the applied method is limited in giving accurate constrains of vertical displacements.

\section{Regional and Local Ground Deformation}

The Andaman-West Sunda arc defines a nearly $2200 \mathrm{~km}$ long subduction zone which through its oblique nature leads to an almost parallel to the plate motion (strike-slip motion) in the Andamans region and predominantly thrust motion at the Sumatra fault system (Curray et al. 1979, McCaffrey 1992, Curray 2005) (Fig.2). The age of the subducting plate increases from about 60 to 90 million yr between Sumatra in the south and Andaman in the north, a fact that may also affect the subduction process (Lay et al. 2005).

Analyzing hypocentral data from shallow seismicity and available source mechanisms covering the period from 1964 to 1993 (Radha Krishna and Sanu 2002) concluded that compressional stresses dominate the entire fore arc and the northern Sumatra region, while tensional stresses prevail in the back arc spreading Andaman sea region. The vertical component of deformation is expressed as crustal thinning in the Andaman Sea and crustal thickening all along the fore arc region. Similar results are also presented from other researches (Jade et al. 2005). The above results are consistent with the overall tectonics of the region (Curray 2005).

Nearly orthogonal convergence at southern Sumatra with slip rates at $\sim 63-68 \mathrm{~mm} / \mathrm{yr}$ (Michel et al. 2001, Bock et al. 2003), steadily decrease to the north and reaches along Sumatra rates of 45 $\mathrm{mm} / \mathrm{yr}$ for the perpendicular to the trench component and $11-28 \mathrm{~mm} / \mathrm{yr}$ for the parallel one (Sieh and Natawidjaja 2000). More to the north where the trench becomes parallel to the direction of relative plate motion, sparse geodetic data suggest a convergence rate of between 14 and $34 \mathrm{~mm} / \mathrm{yr}$ (Bilham et al. 2005). 


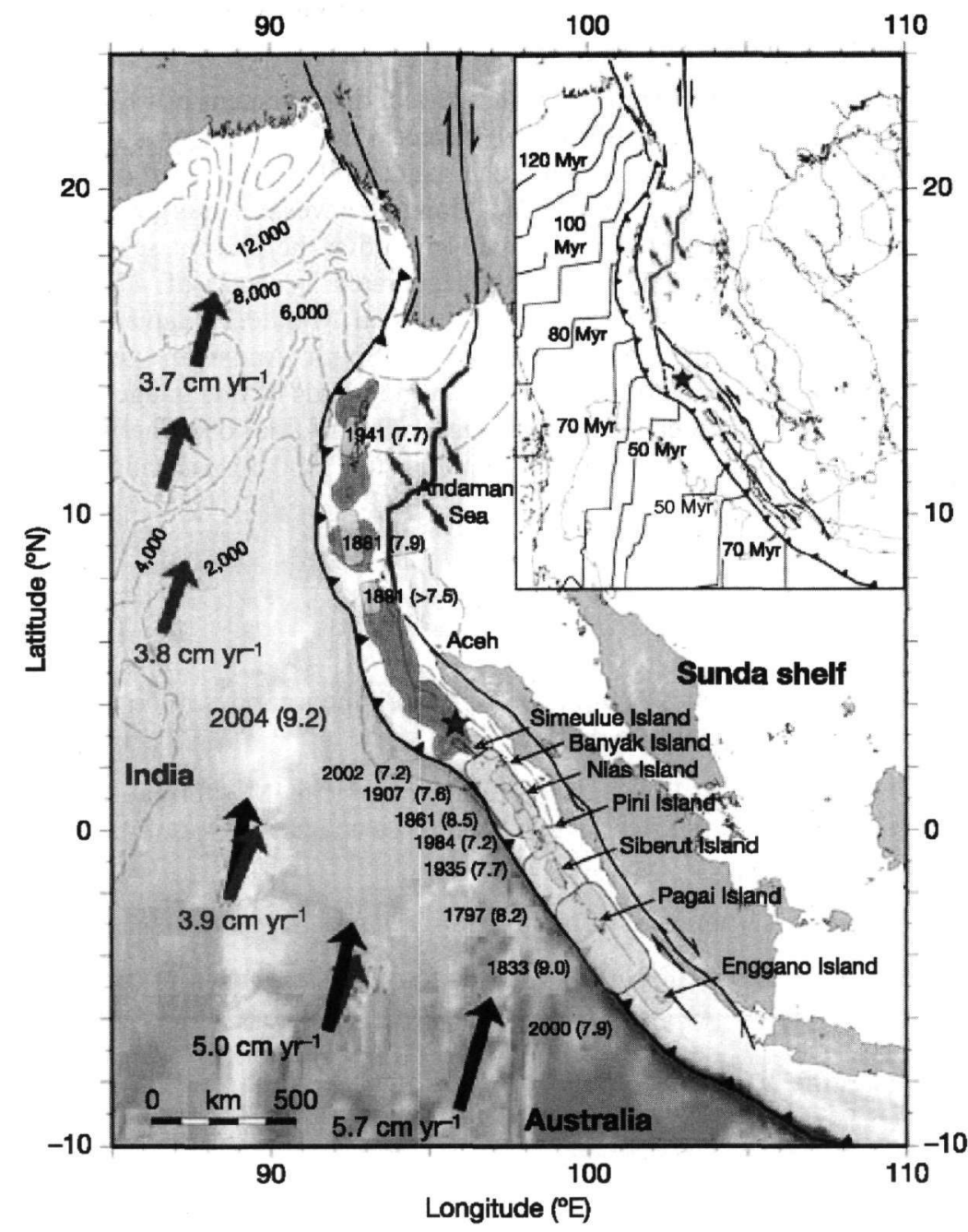

Figure 2 - Geotectonic setting of Sumatra-Andaman region. The inset shows the along the Sumatra-Andaman trench northward increase of sea floor age (from Subarya et al. 2006).

Tectonic features are simplified from Natawidja et al. 2004 and Curray 2005

The magnitudes of the observed co-seismic displacements at all sites attest the rupture extend up to North Andaman Island. According to Earnest et al. 2005 though, the southern groups of islands show greater displacement compared to the Andaman segment. Local GPS networks suggest horizontal co-seismic displacement of $1.5-6.5 \mathrm{~m}$ in the Andamans, with an intervening low displacement of 1.5-2 $\mathrm{m}$ in Middle Andaman Island (Gahalaut et al. 2006). The above values are consistent with other sparse GPS observations (Jade et al. 2005, Nagarajan et al. in press). It is interesting that static co-seismic offsets $>1 \mathrm{~mm}$ were observed up to $7800 \mathrm{~km}$ away from the great Sumatra-Andaman earthquake using global GPS network data (Kreemer et al. 2006). Co-seismic displacement vectors as well as these referred entirely to the aftershock activity were toward WSW direction.

Field observations and aerial surveys over Andaman show evidence of a widespread uplift along the western coast and downlift on the eastern part (Ernest et al. 2005, Jain et al. 2005). This is manifested mainly in the form of elevated shore lines and coastal terraces, uplifted coral beds and 
emerged mangrove swamps. Co-seismic downlift decreases to the east as seen at Havelock Island where not any significant change was registered.

Pre- and post-earthquake GPS campaigns indicate vertical displacement of -1.36 to $+0.63 \mathrm{~m}$ along the arc (Ernest et al. 2005). Notable uplift was observed in the northern parts of Andaman to Land Fall Island. Specifically at Diglipur where GPS campaigns indicate an uplift of $63 \mathrm{~cm}$, a recession of shoreline of about $60-80 \mathrm{~cm}$ was observed. Along the western margin of Interview Island patches of elevated corals are exposed more than $1 \mathrm{~m}$ above the present sea level (Ernest et al. 2005). However coral measurements may be exaggerated because of $47 \mathrm{~cm}$ of tidal level differences (Tobita et al. 2006). While some locations in Middle Andaman show evidence of uplift, Port Blair located on the eastern margin of South Andaman generally downlifted. Measurements of the observed downlift were given from records of tide gauge and were estimated at $\sim 1 \mathrm{~m}$ (Ernest et al. 2005). Farther to the south according to tidal data the west facing parts of North Sentinel Island uplifted about $0.75 \mathrm{~m}$, while Little Andaman Island shows no change (Gahalaut et al. 2006).

\section{Data Used and Processing}

\subsection{Data Collection}

The data used to achieve the objectives of the present work incorporates remotely sensing products of different earth observation systems including,

(i) A data set of ENVISAT ASAR IS2 descending images, in IMP format, covering the entire island of Andaman, before and after the seismic event. The characteristics of the ASAR images are summarized in Table 1.

(ii) Landsat 7 ETM+ images from visible and near infrared spectral bands.

Table 1 - Characteristics of ENVISAT ASAR images used in the study.

\begin{tabular}{|c|c|c|c|c|c|c|}
\hline Track & Frame & Orbit & Swath & Mode & Polarization & $\begin{array}{c}\text { Acquisition } \\
\text { Date }\end{array}$ \\
\hline \multirow{3}{*}{233} & \multirow{3}{*}{3375} & 11810 & \multirow{3}{*}{ IS2 } & \multirow{3}{*}{ Descending } & VV & $03 / 06 / 2004$ \\
\hline & & 14816 & & & $\mathrm{HH}$ & $30 / 12 / 2004$ \\
\hline & & 15818 & & & VV & $10 / 03 / 2005$ \\
\hline
\end{tabular}

\subsection{Processing Steps}

The ASAR intensity images were processed following the creation of a "window" containing the study area, for radiometric correction and enhancement. Intensity of a backscattering microwave signal strongly depends on the roughness of the surface. The main problem associated with SAR images is speckle noise that is caused by random effect of many individual reflectors within each pixel. The overall result is an image with "salt and pepper" texture which produce difficulties in image interpretation.

In order to reduce the speckle noise, a number of specific filters dedicated to noise reduction have been proposed. In this case the enhanced Lee adaptive filter (Lopes et al. 1990) was used iteratively, using two successive passes of the filter applying different parameters each time for sigma multiplier ( 0.5 and 1.0$)$ and window size $(3 \times 3$ and $5 \times 5)$. For the implementation of the filter the specific coefficient of variation value of each image was calculated, whilst each image was divided into areas of three classes. The first class corresponds to homogeneous image patches in which the speckle may be easily eliminated, the second class to heterogeneous image patches in 
which the speckle is to be reduced while preserving texture and the third one to image patches containing isolated point targets for which the filter should preserve the already existing values. Furthermore, using as reference the pre-seismic image (acquired on 03/06/2004), the scenes were coregistered and geocoded. As the accuracy of the coregistration between the SAR scenes is of great importance, the RMS value of the polynomial transformation of all pairs was decisively less than a pixel.

To detect areas of backscatter changes the processed SAR scenes were combined to generate a single multi-temporal image. The multi-temporal image is simply the result of assigning intensity variations of the three processed SAR images to each of the primary colours, to form an RGB image composition. Intensity variation of the pre-seismic image dated 03/06/2004 (orbit 11810) was assigned to blue, while variations of post-seismic images dated 30/12/2004 and 10/03/2005 (orbits 14816 and 15818) to green and red respectively (Fig. 3). Examples of the colour additive process for different regions of Andaman are given in Figures 4, 5 and 6.
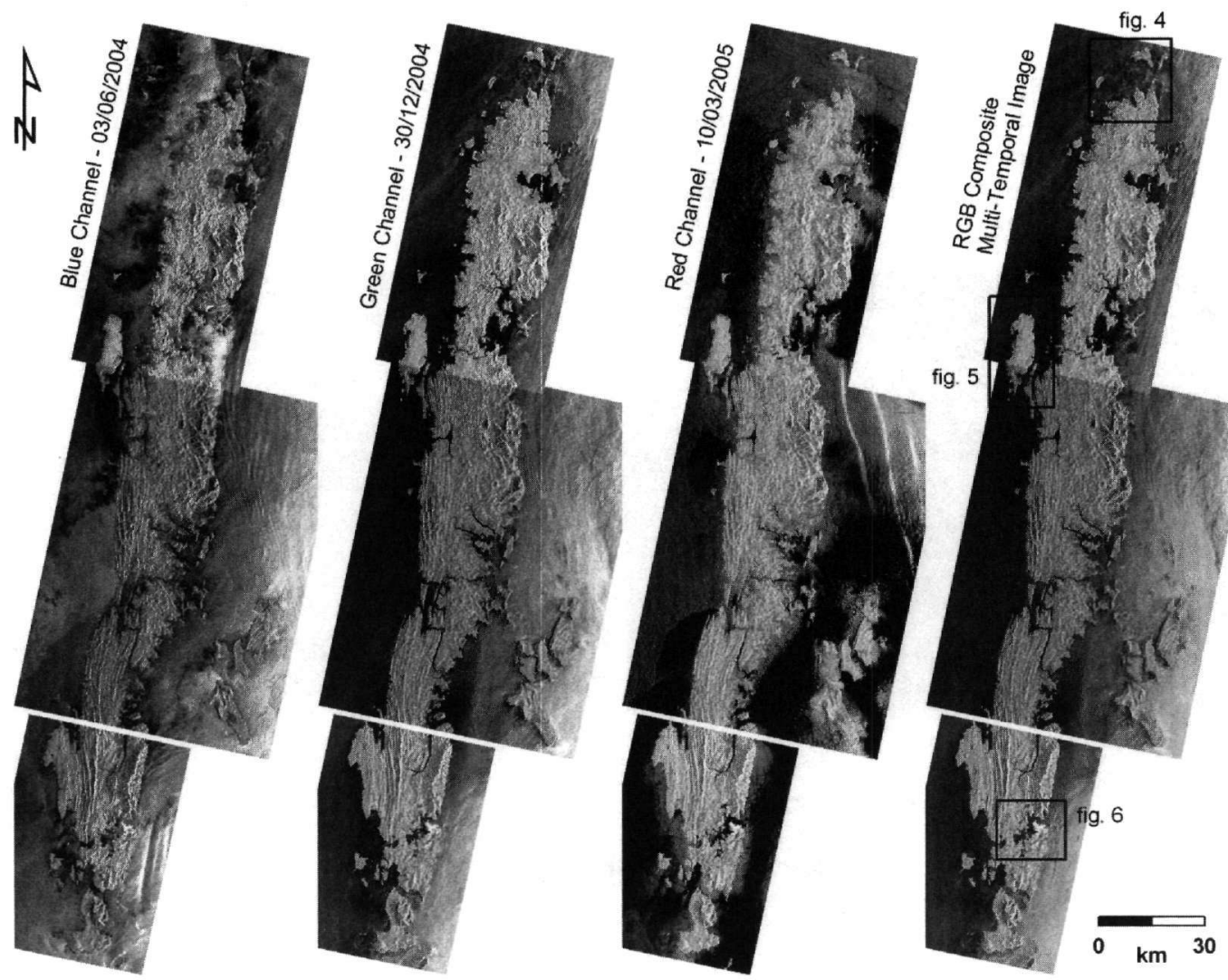

Figure 3 - Assignment of additive colours (RGB) to the acquired ENVISAT ASAR images to generate a multi-temporal SAR image. Locations of figures 4, 5 and 6 are also shown

Additionally to SAR data, optical satellite images were used as a supplementary source of information. Due to the nature of optical data, their potential for recognition of elevation changes is limited. Thus, they were used only to document the presence of coral reefs along the shorelines. Imagery from Landsat $7 \mathrm{ETM}+$ satellite acquired before the earthquake were collected and processed. Spectral bands of the visible part (band 1) of the Electromagnetic Spectrum (EMS) and the middle infrared (band 5) were interpreted to map the coral reefs. The dramatic difference of the spectral response between water mass and land (coral reefs) in these two parts of the EMS was the criterion for the presence or no of coral reefs. 


\section{Results and Discussion}

Analysis of satellite radar images provided an outline of coastal regions that experienced coseismic vertical deformation. Colour display in the generated multi-temporal image is due to changes in the backscattering coefficients between the dates of acquisition of the three SAR images. Changes in the signal backscattering in this case could be attributed to change provoked by the earthquake and/or to secondary phenomena (e.g. tsunami inundation). These changes increase or decrease the reflection intensity of SAR images. Offshore multicolour display in the multi-temporal image is mainly produced by the different sea-state between the three acquisitions. Where the land characteristics remain stable these areas are shown in levels of grey.

According to the selected RGB composition (Fig. 3) areas subjected to positive elevations changes (uplift) appear with variations of green, whereas sites with negative changes (downlift) are expressed by variation of blue. Generally remarkable uplift was detected at the northern parts of Andaman and at Land Fall Island (Fig. 4). Noticeable uplift was observed as well along the western margins of Andaman and at Interview Island (Fig. 5). However the marks of uplift become less evident along the western coasts of Middle and South Andaman. On the other hand at some sites, mainly at the south-eastern margins of the island, marks of downlift are recognized. A typical case is the area of Port Blair (Fig. 6) were field observations indicate change that reached almost $1 \mathrm{~m}$. All the above results are in agreement with tidal data and field observations mentioned in a previous chapter.

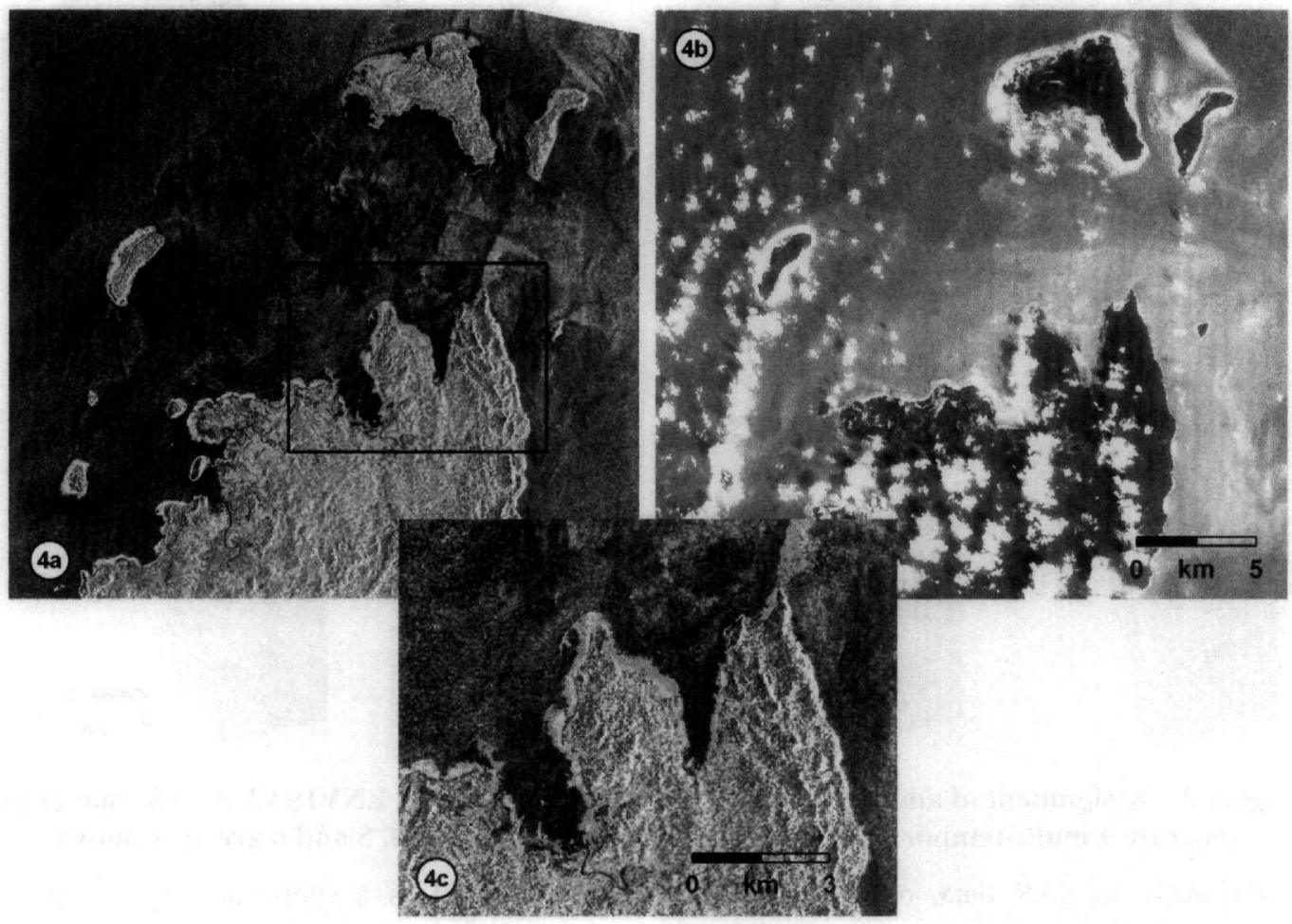

Figure 4 - North Andaman and Land Fall Island shoreline changes related to co- and postseismic deformation of December 2004 earthquake. Multi-temporal SAR image (4a-c) and Landsat ETM+ band 1 image (4b). Variations of green correspond to uplifted areas due to the earthquake and yellow patches to areas still emerged approximately three months after the main event 

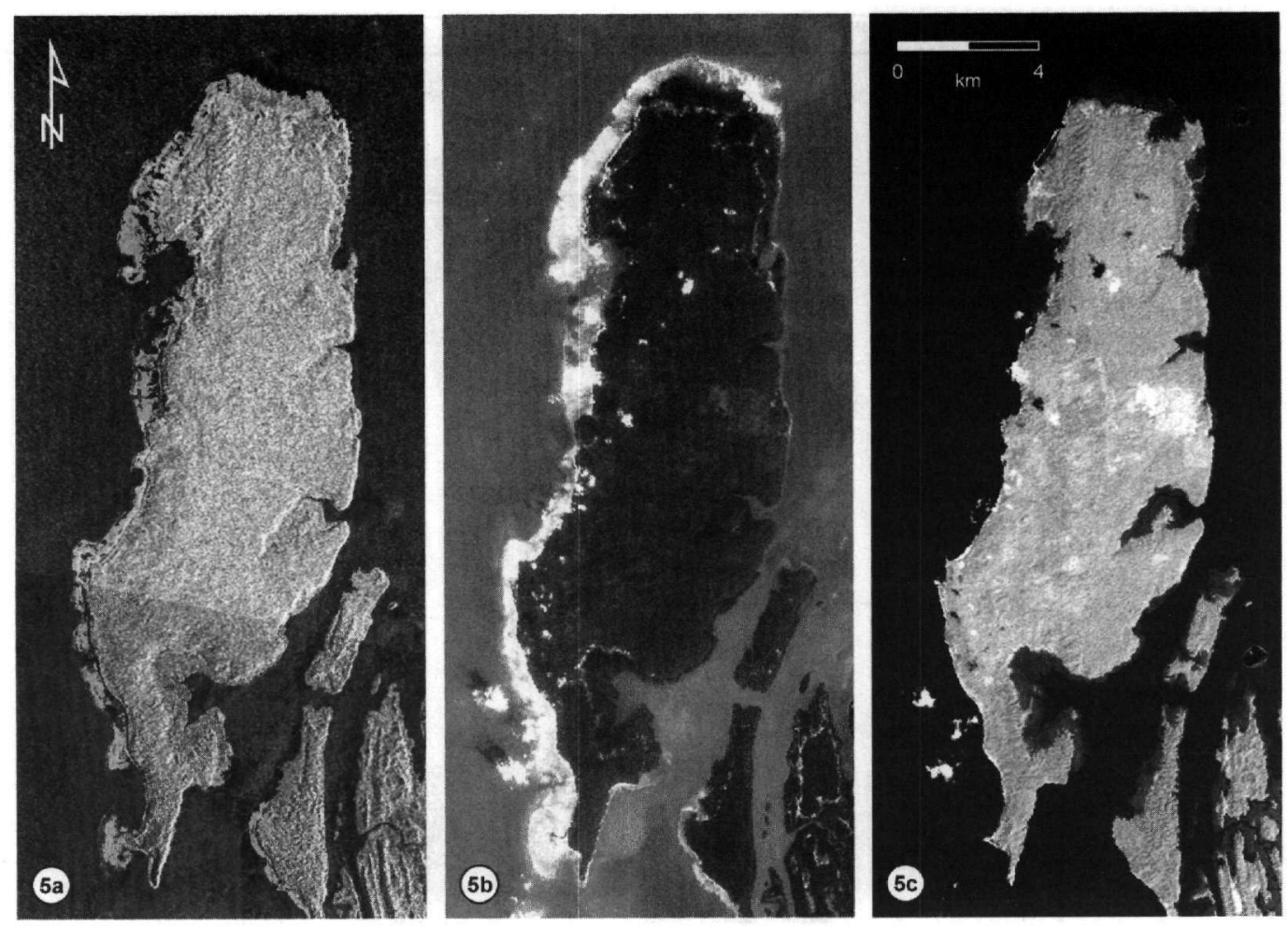

Figure 5 - Example of vertical deformation along Interview Island. Multi-temporal SAR image (5a) and Landsat ETM+ band 1 and band 5 images ( $5 \mathrm{~b} \& 5 \mathrm{c}$ respectively)
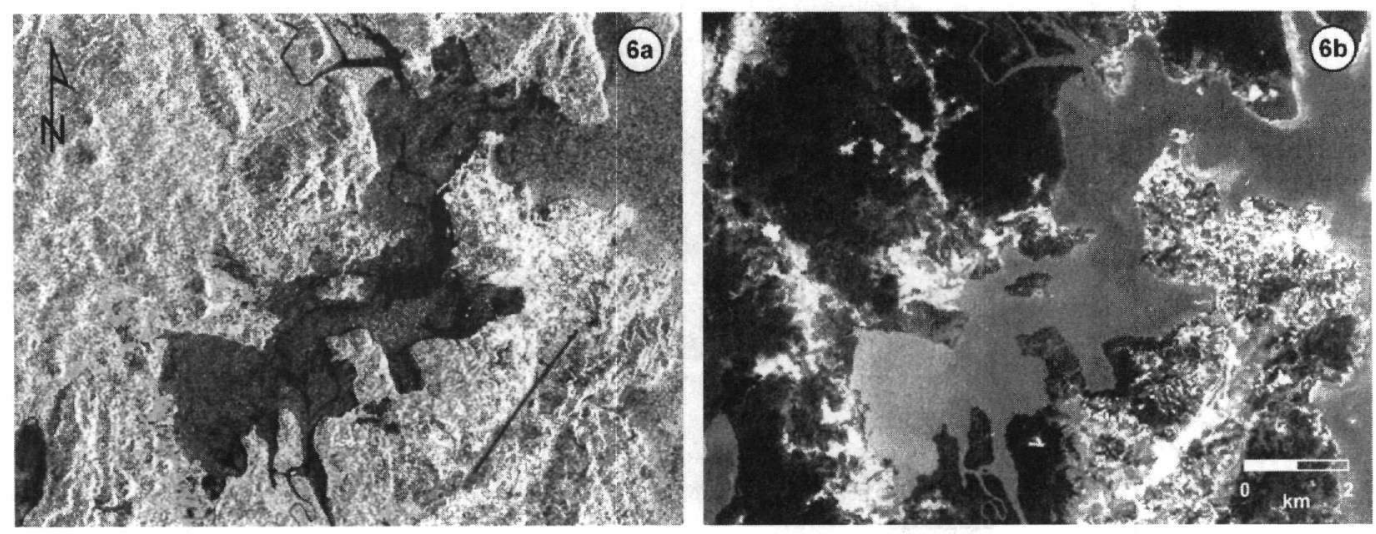

Figure 6 - Detected downlift at Port Blair, located at the SE part of Andaman Island. Multitemporal SAR image (6a) and Landsat ETM+ band 1 (6b). Variations of blue represent areas of submergence due to tectonic motion of the 2004 Sumatra-Andaman earthquake

Although uplift should be attributed almost to deformation following the main seismic event, downlift phenomena should be considered more carefully as they may also be caused by coastal erosion by tsunami. However no tsunami inundations at least along the eastern margin of the islands have been reported. Analytical map showing the spatial pattern of the detected vertical motion related to the Sumatra-Andaman earthquake in the Andamans is presented in Figure 7. It is important to notice that the identification of uplifted shorelines was achieved because of low water 


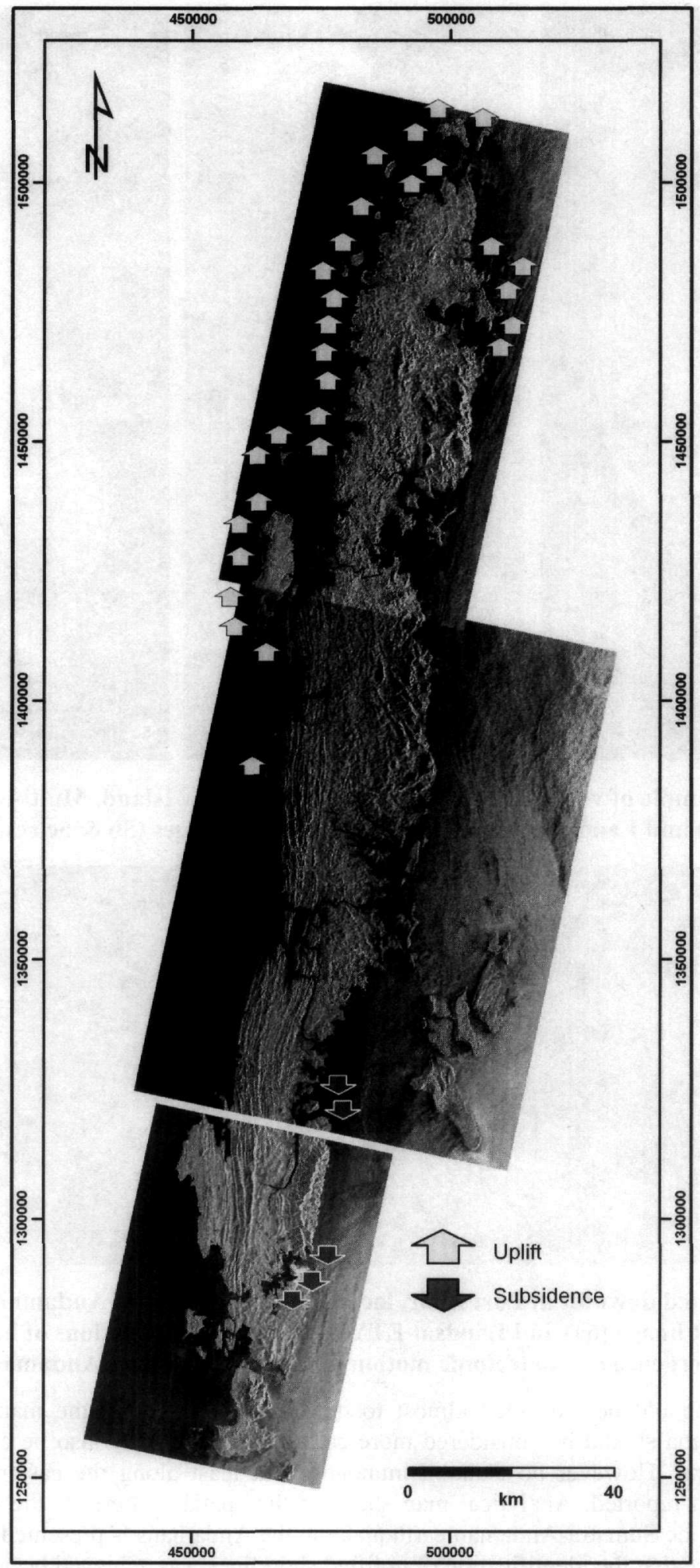

Figure 7 - Detected elevation changes (uplift or downlift) along the shorelines of Andaman Island, derived from ENVISAT ASAR data. Projection in UTM WGS'84 Zone 34 North 
depths and presence of coral reefs as revealed from optical satellite data. Such parameters control the extent of land exposure that follows vertical tectonic movements.

Of great significance is the banding recognised in the multi-temporal image and expressed as an inner yellow zone between the old pre-seismic shoreline and the uplifted areas displayed in green. Such yellow patches are the result of red and green additive process and correspond to differences of backscattering intensity between the two post-seismic SAR scenes. It appears that a wide costal area was uplifted immediately after the main seismic event, but yet not all the exposed corals continue to emerge and only a narrower zone close to the pre-seismic shoreline was preserved (Figs 4-6). Possible explanations involve either the possibility of post-seismic relaxation of the firstly uplifted areas, either the raise of sea level due to tidal phenomena. It is obvious that the major source of error is tidal level differences between the acquisition times of SAR imagery. In any case local GPS measurements and tidal data for the post-seismic period are needed in order to explain the observed banding.

Microwave data was proven to be an excellent tool to assess relative coastline changes both in spatial and temporal sense. On the contrary to optical satellite images such data offer the advantage of cloud penetration and stable backscattering intensities. Regardless its qualitative nature, since only the sign of elevation change can be detected, the revealed overview of uplift and submergence pattern could be used as constrains in deformation modelling research.

\section{Acknowledgments}

The authors would like to acknowledge the European Space Agency (ESA) for providing the ENVISAT ASAR data.

\section{References}

Ammon, C.J., Chen, J., Thio, H.-K., Robinson, D., Sidao, N., Hjorleifsdottir, V., Kanamori, H., Lay, T., Das, S., Helmberger, D., Ichinose, G., Polet, J., and Wald, D., 2005. Rupture process of the 2004 Sumatra-Andaman earthquake, Science, 308, 1133-1139.

Anu, R., and Rajendran, K., 2006. Co-seismic deformation along the Andaman-Nicobar arc based on GPS data and ground observations, Proc. Of the XVIII Kerala Science Congress, Akkulam, 29-31 January, 226-228 (Extended Abstract).

Banerjee, P., Pollitz, F.F., and Bürgmann, R., 2005. The size and duration of the SumatraAndaman earthquakes from far-field static offsets, Science, 308, 1769-1772.

Bilham, R., 2005. A flying start, then a slow slip, Science, 308, 1126-1127.

Bilham, R., Engdahl, R., Feldl, N., and Satyabala, S.P., 2005. Partial and complete rupture of the Indo-Andaman plate boundary 1847-2004, Seismol. Res. Lett., 76, 299-311.

Bock, Y., Prawirodirdjo, L., Genrich, J.F., Stevens, C.W., McCaffey, R., Subarya, C., Puntodewo, S.S.O., and Calais, E., 2003. Crustal motion in Indonesia from Global Positioning System measurements, Journal of Geophysical Research, 108(B8), 2367.

Curray, J.R., Moore, D.G., Lawver, L., Emmel, F.J., Raith, R., Henry, M., and Kieckhefer, R., 1979. Tectonics of the Andaman sea and Burma, Am. Assoc. Pet. Geol. Mem., 29, 189-198.

Curray, J.R., 2005. Tectonics and history of the Andaman sea region, J. Asian Earth Sci., 25, 187228.

Earnest, A., Rajendran, C.P., Rajendran, K., Anu, R., Arun, G.M., and Mohan, P.M., 2005. Nearfield observations on the co-seismic deformation associated with the 26 December 2004 Andaman-Sumatra earthquake, Current Science, 89(7), 1237-1244. 
Gahalaut, V.K., Nagarajan, B., Catherine, J.K., and Kumar, S., 2006. Constraints on 2004 Sumatra-Andaman earthquake rupture from GPS measurements in Andaman-Nicobar Islands, Earth and Planetary Science Letters, 242, 365-374.

Guilbert, J., Roueff, A., Vergoz, J., and Cansi, Y., 2005. An original image of the seismic rupture of the Sumatra Mw O 9.0 using PMCC from seismic and hydroacoustic small array, Geophys. Res. Lett., 32, doi:10.1029/2005GL022966.

Jade, S., Ananda, M.B., Dileep Kumar, S.P., and Banerjee, S., 2005. Coseismic and postseismic displacements in Andaman and Nicobar Islands from GPS measurements, Current Science, 88, 1980-1984.

Kreemer, C., Blewitt G., Hammond W.C., and Plag, H.-P., 2006. Global deformation from the great 2004 Sumatra-Andaman earthquake observed by GPS: Implications for rupture process and global reference frame, Earth Planets Space, 58, 141-148.

Lay, T., Kanamori, H., Ammon, C.J., Nettles, M., Ward, S.N., Aster, R.C., Beck, S.L., Bilek, S.L., Brudzinski, M.R., Butler, R., DeShon, H.R., Ekström, G., Satake, K., and Sipkin, S., 2005. The Great Sumatra-Andaman earthquake of 26 December 2004, Science, 308, 1127-1133.

Lopes, A., Touzi, R., and Nezry, E., 1990. Adaptive speckle filters and scene heterogeneity, IEEE Transaction on Geosciences and Remote Sensing, 28(6), 992-1000.

McCaffrey, R., 1992. Oblique plate convergence, slip vectors, and fore-arc deformation, Journal of Geophysical Research, 97(B6), 8905-8915.

Michel, G.W., Becker, M., Reigber, Ch., Tibi, R., Yu, Y.Q., and Zhu, S.Y., 2001. Crustal motion and block behavior in SE-Asia from GPS measurements, Earth and Planetary Science Letters, 187, 239-244.

Nagarajan, B., Kumar, S., Catherine, J.K., and Gahalaut, V.K., in press. Coseismic displacements in Andaman-Nicobar Island due to 26 December 2004 Sumatra earthquake, Journal of Earth System Science.

Natawidjaja, D.H., Sieh, K., Ward, S.N., Cheng, H., Edwards, R.L., Galetzka, J., and Suwargadi, B.W., 2004. Paleogeodetic records of seismic and aseismic subduction from central Sumatran microatolls, Indonesia, Journal of Geophysical Research, 109, B04306.

Newcomb, K.R., and McCann, W.R., 1987. Seismic history and seismotectonics of the Sunda Arc, Journal of Geophysical Research, 92, 421-439.

Ni, S., Kanamori, H., and Helmberger, D., 2005. Energy radiation from the Sumatra earthquake, Nature, 434, 582.

Radha Krishna, M., and Sanu, T.D., 2002. Shallow seismicity, stress distribution and crustal deformation pattern in the Andaman-West Sunda arc and Andaman Sea, northeastern Indian Ocean, Journal of Seismology, 6, 25-41.

Sieh, K., 2005. What happened and what's next?, Nature, 434, 573-574.

Sieh, K., and Natawidjaja, D., 2000. Neotectonics of the Sumatran fault, Indonesia, Journal of Geophysical Research, 105, 28295-28326.

Stein, S., and Okal, E.A., 2005. Speed, Speed and size of the Sumatra earthquake, Nature, 434, 581-582.

Subarya, C., Chlieh, M., Prawirodirdjo, L., Avouac, J.-P., Bock, Y., Sieh, K., Meltzner, A.J., Natawidjaja, D.H., and McCaffrey R., 2006. Plate-boundary deformation associated with the great Sumatra-Andaman earthquake, Nature, 440, 46-51. 
Tobita, M., Suito, H., Imakiire, T., Kato, M., Fujiwara, S., and Murakami, M., 2006. Outline of vertical displacement of the 2004 and 2005 Sumatra earthquakes revealed by satellite radar imagery, Earth Planets Space, 58, e1-e4.

Vigny, C., Simons, W.J.F., Abu, S., Ronnachai Bamphenyu, Chalermchon Satirapod, Nithiwatthn Choosakul, Subarya C., Socquet A., Omar K., Abidin, H.Z., and Ambrosius, B.A.C., 2005. Insight into the 2004 Sumatra-Andaman earthquake from GPS measurements in southeast Asia, Nature, 436, 201-206.

Zachariasen, J., Sieh, K., Taylor, F.W., and Hantoro, W.S., 2000. Modern vertical deformation above the Sumatran subduction zone: paleogeodetic insights from coral microatolls, Bull. Seism. Soc. Am., 90, 897-913. 